\title{
Impact of Turnover Intention on Loneliness and the Mediating Effect of Work Alienation
}

\author{
İzlem Gözükara \\ Dept. of Business Administration, Istanbul Arel University, Tepekent, Istanbul, Turkey \\ Tel: 90-532-486-5455Ｅ-mail: izlemg@arel.edu.tr
}

\begin{abstract}
A. Çiğdem Mercanlı
Department of Health Management, Istanbul Bilgi University, Turkey

Tel: 90-444-0428Ｅ-mail: cigdem.mercanlioglu@bilgi.edu.tr
\end{abstract}

\section{Selçuk Capuk}

Civil Air Transportation Management, Nişantaşı University, Turkey

Tel: 90-212-210-1010Ｅ-mail: selcuk.capuk@ nisantasi.edu.tr

\begin{abstract}
Osman Y1ldırım
Department of Electrical and Electronics Engineering, Istanbul Arel University, Tepekent, Istanbul, Turkey

Tel: 90-850-850-2735 E-mail: osmanyildirim@arel.edu.tr
\end{abstract}

Received: Dec. 29, 2016 Accepted: January 11, $2017 \quad$ Published: January 21, 2017

doi:10.5296/bms.v8i1.10521 URL: http://dx.doi.org/10.5296/bms.v8i1.10521

\begin{abstract}
High levels of labor turnover are considered signals of poor management for organizations. The departure of qualified employees may result in great losses in organizational terms. This research aimed to examine the relationships between turnover intention, work alienation, and
\end{abstract}


loneliness. Research data were collected using surveys from 440 aviation company employees, and convenience sampling was used for participant selection. The survey included UCLA Loneliness Scale, Work Alienation Scale, and Turnover Intention Scale. The research revealed that turnover intention had an effect on loneliness and this effect of turnover intention on loneliness was fully mediated by work alienation. Accordingly, work alienation fully mediates the relationship between turnover intention and loneliness. The analyses indicate that organizations, especially in the aviation industry, should pay attention to psychological factors such as loneliness and work alienation that drive qualified employees to quit their jobs. This research contributed to the relevant literature by pointing out organizational behavior concepts that may lead to unexpected labor loss and thereby inefficiency.

Keywords: Work alienation, Turnover intention, Loneliness, Structural equation model 


\section{Introduction}

Today, employees who have unsatisfied expectations and feel frustrated in psychological, physical and financial terms lead to reduced professional efficiency, resulting in departures (Yıldirım, Erul, \& Kelebek, 2014). Turnover intention, the opinion of an employee to quit his or her job in a near future (Şahin, 2011), is an important management topic which has been discussed in recent studies (e.g., Hom \& Griffeth, 1991; Telli, Ünsar, \& Oğuzhan, 2012) with regard to its predictive role in actual departures.

Employee turnover creates a considerable organizational cost (Arshadi \& Shahbazi, 2013). This makes turnover intention significant for organizations to take necessary and expedient actions. Turnover intention is widely agreed to influence organizational efficiency. By establishing the factors with effect on turnover intention, management researchers are able to predict and explain employees' intentions to leave, while managers can formulate precautions to avoid potential resignations (Hwang \& Kou, 2006).

As a psychological-based factor, loneliness is considered the inability to establish desired social dialogues (Nurmi \& Katariina, 1997; Savikko, Routasalo, Tilvis, Strandberg, \& Pitlaka, 2005). Loneliness at work occurs when one is excluded and isolated from social environment within an organization (Wright, Burt, \& Strongman, 2006). Loneliness has an effect on work life just as it does on personal life. It is important for an individual to have serenity and safety at a workplace.

One's detachment from the organization psychologically, physically or both is an indicator of alienation (Tuna \& Yeşiltaş, 2014). Work alienation refers to one's incapacity of self-expression at work (Suárez-Mendoza \& Zoghbi-Manrique-de-Lara, 2008). An alienated employee refers to an individual who feels disengaged from work and uninvolved in his or her role at work (Sulu, Ceylan, \& Kaynak, 2010). Work alienation is closely related with working conditions (DiPietro \& Pizam, 2008). According to Ünsar and Karahan (2011), work alienation results in leaving the job. From this perspective, this study aspires to reveal how loneliness at work is affected by turnover intention and whether work alienation mediates the loneliness-turnover intention relationship.

\section{Turnover Intention}

Turnover is withdrawal from an organization permanently either on a voluntary or an involuntary basis (Robbins, Judge, Odendaal, \& Roodt, 2009). Turnover intention, in turn, is employees' intention to continue or leave their current work relationship (Lacity, Lyer, \& Rudramuniyaiah, 2008).

According to Vandenberg and Nelson (1999), the intention of employees to leave is the likelihood of a permanent withdrawal from their organization in the near future. The intention to stay, in turn, reflects the extent to which employees are committed to their organization and are willing to continue their employment (Hewitt, 2004). As shown by various studies, intention is the most significant determinant of actual turnover (e.g. Tett \& Meyer, 1993; 
Igbaria \& Greenhaus, 1992). Besides, empirical research has proven that the intention of an employee to stay or leave has a consistent and strong association with voluntary turnover (Dalessio, Silverman, \& Schuck, 1986; Mathieu \& Zajac, 1990).

The literature rarely contains a precise definition of turnover intention and this is a consequence of the perception that people consider the term self-explanatory (Bester, 2012). For instance, Rusbult, Farrell, Rogers and Mainous (1988) have suggested that turnover intention is the active and detrimental actions of individuals when they are not satisfied with their work conditions. Some scholars conceptualize turnover intention as the extent to which an employee desires and plans to quit the organization (e.g. Lacity et al., 2008; Sousa-Poza \& Henneberger 2004), while others (e.g. Mobley, Horner, \& Hollingsworth, 1978; Tett \& Meyer, 1993) approach this concept as a conscious and thoughtful desire to leave an organization.

The theory of Reasoned Action and Planned Behavior by Fishbein and Ajzen (1975) suggests that a planned behavior is likely to be predicted by the intention to perform such behavior. This behavioral intention concept proposes that individuals rationally reach a decision by "systematically employing accessible information on the costs and benefits of the behavior and the control they have, or believe they have, over carrying it out" (Chacon, Vecina, \& Davila, 2007, p. 628). Drawing on this theory, turnover intention can be defined as the behavioral intention of an employee to quit the organization.

Both at organizational and individual levels, employee turnover is a critical issue for human resources. From the organizational standpoint, increased employee turnover represents loss of qualified employees, which leads to increased investment costs in training of replaced employees (Liu, Liu, \& Hu, 2010). It may damage organizational productivity when a critical and effective employee leaves (Cascio, 2010). Turnover also leads to interruption in organizational activities, because of which it is often considered a negative influence on organizational productivity and efficiency (Aykan, 2014). On the other hand, turnover intention may provide certain advantages such as the departure of a low-performing employee (Cascio, 2010) whose replacement may bring certain advantages such as novel information, capabilities and skills among other favorable changes (Mobley, 1982).

Regarding the factors, which affect turnover intention, Sias and Cahill (1998) found that informal relationships within an organization have an enhancing influence on employee commitment, job satisfaction, and turnover intention. Bakker, Schaufeli, Leiter, \& Taris (2008), in turn, suggest that turnover intention is negatively and significantly affected by job resources such as social support, manager guidance, feedback and time control. Work engagement or commitment plays a mediating role in such relationship. Taboli (2015) demonstrated a negative relationship between work engagement and turnover intention, whereas burnout and work alienation positively affect turnover intention. It has also been found less likely for employees who identify themselves with their organization to leave, as they desire to maintain such identity (van Dick et al., 2004; van Knippenberg, van Dick, \& Tavares, 2007). 


\section{Loneliness}

Loneliness is a constant affective disorder, which occurs when one feels alienated, misunderstood and rejected or when one is deprived of social associations for activities or opportunities toward social affection and integration (Rook, 1984). According to Weiss (1973), loneliness has two forms; social and emotional. Social loneliness is the form related to one's social relations and it is often accompanied by distress and depression resulting from social support deprivation. Emotional loneliness, on the other hand, is related to the absence of closeness to another individual and includes feelings such as emptiness and anxiety. Despite the unclear association between the two loneliness types, there is a consensus that relationship is the basis of both types (Kaymaz, Eroğlu, \& Sayılar, 2014).

The literature review points out three main assumptions employed to examine the loneliness concept (Kraus, Davis, Bazzini, Church, \& Kirchman, 1993). The first one assumes that loneliness is a perception of incapability and originates from one's social lifestyle. The second assumption approaches loneliness as a subjective feeling that has a direct relationship with one's experiences. The last one suggests that loneliness is an undesirable and troublesome feeling. All three assumptions have paved the way for scientific research on loneliness.

Loneliness at work refers to the situation resulting from poor social relations with others at work and leading to distress (Wright et al., 2006). Psychological factors experienced at work, such as loneliness, are likely to have a negative influence on both individuals and organizations. Interpersonal relationships and employee performance suffer for individuals while organizational commitment is compromised for the employer (Y1lmaz, 2008). When an employee has an intention to leave an organization, loneliness suggests an undesired climate in the organization (Wright et al, 2006).

There is limited research on loneliness at work and its effects in the Turkish literature, contrary to the foreign literature. Among these, Demir (1989) conducted the reliability and validity study of UCLA loneliness scale; Y1lmaz (2008) examined life satisfaction and organizational commitment; Doğan, Çetin and Sungur (2009) provided the Turkish form of the scale for loneliness at work and Erdil and Ertosun (2011) investigated the link between organizational commitment and loneliness at work.

The study by Erdil and Ertosun (2011) suggests that loneliness at work has an adverse effect on employee's social and professional life. Their findings demonstrated that employees feel less loneliness when the organization creates a social climate for establishing positive relationships, and they concluded that the role of social climate in loneliness at work is fundamental and determinative. The study by Aytaç (2015) showed that employees who feel loneliness at work also have turnover intentions. Likewise, Aykan (2014) demonstrated that emotional loneliness plays a mediating effect on turnover intention when employees believe that their contract is violated at work and emotional loneliness enhances such turnover intentions. Demirbaş and Haşit (2016) established a significant and positive relationship 
between loneliness at work and intention to leave. Drawing on this theoretical background, we develop the following hypothesis:

\section{$\mathrm{H}_{1}:$ Turnover intention has a positive effect on loneliness.}

\section{Work Alienation}

Alienation is a situational construct resulting from particular conditions rather than a stable personality factor (Seeman, 1983). It is a concept that has been studied for a long time (Nair \& Vohra, 2010). Fromm (1955) and Seeman (1959) provided great insights to the concept of alienation, which have driven researchers to analyze this concept from the perspectives of different disciplines including sociology (e.g., Blauner, 1964), social psychology (e.g., Maadi, Kobasa, \& Hoover, 1979) and organizational science (e.g., Podsakoff, Williams, \& Todor, 1986). However, the work of Seeman is groundbreaking in definitional terms. Seeman conceptualized alienation based on the absence of certain conditions including powerlessness (refers to being incapable of controlling environmental situations), meaningless (refers to the perceived insignificance of work outcomes), normlessness (refers to the inability of applying norms), isolation (refers to unmet affiliation need) and self-estrangement (refers to unsatisfactory conditions at work).

In organizational context, alienation typically implies employees' non-internalization of their tasks at work (Organ \& Greene, 1981). However, in psychological context, researchers have focused on work involvement as the opposite of alienation (Lodahl \& Kejner, 1965). Accordingly, alienation is a psychological state of feeling dissociated from work (Kanungo, 1979). Since there are various definitions, we discussed work alienation as the feeling of detachment from work (Organ \& Greene, 1981) for the purposes of our research. In this sense, work alienation represents the situation where an employee feels unattached, unconcerned and uninterested about their job (Kanten \& Ülker, 2014). Such feeling of work alienation may result in adverse consequences for both the organization and employees (Ceylan \& Sulu, 2011; Chiaburu, Diaz, \& De Vos, 2013).

The literature contains several studies conducted concerning which factors and outcomes are associated with work alienation, including job characteristics and leadership styles, inadequate decision-making, restricted autonomy, job involvement, organizational commitment, organizational justice and perceived structure of the organization (DiPietro \& Pizam, 2008; Banai \& Reisel, 2007; Ceylan \& Sulu, 2011; Kanten \& Ülker, 2014; Sulu et al., 2010; Nair \& Vohra, 2010). Besides, work alienation may affect employee attitudes and behaviors. For instance, the study by Golden, Veiga and Dino (2008) suggested that employees experiencing alienation at work have lower levels of satisfied need toward belonging and fewer reasons to continue their employment. Banai and Reisel (2007) stated that psychological states are likely to be positively affected in the presence of a well-designed job. Tuna and Yeşiltaş (2014) established that identification and alienation affect turnover intentions. The study by Ünsar and Karahan (2011) indicated that work alienation results in leaving the job over time, while Sulu et al. (2010) highlighted that alienation leads to 
decrease in motivation causing employees to start feeling psychologically detached from their job. Based on the above background, we develop the following hypothesis:

$\mathrm{H}_{2}$ : Work alienation mediates the turnover intention - loneliness relationship.

\section{Methods}

\subsection{Research Goal}

This study has two objectives. The first one is to discover whether turnover intention and loneliness at work are related. The second one is to reveal whether work alienation has a mediating effect on such relationship.

\subsection{Participants and Procedure}

A questionnaire was conducted with 480 participants, 40 of which were considered invalid due to missing information, so 440 questionnaires were obtained in full. $75 \%$ of the participants were male, $65 \%$ had a minimum of 3 years work experience, and $68 \%$ had a bachelor's degree. Based on age groups, $10 \%$ of the participants were under 25 years of age, $35 \%$ were aged between 25 and 29, 25\% were aged between 30 and 34, and the remainder aged 35 and above. Concerning their positions, $5 \%$ were administrators, $5 \%$ were engineers, $15 \%$ were technicians, $25 \%$ were personnel, and the remaining participants were workers.

\subsection{Measures}

Turnover Intention Scale was used to measure turnover intention. This instrument includes three items (e.g. "I often think about quitting my job"). It was developed by Cammann, Fichman, Jenkins and Klesh (1983). The items were responded on a 5-point Likert system. The higher score suggests greater intention to leave a job. The reliability coefficient in this study was 0.930 .

Work Alienation Scale was used to measure work alienation. This instrument includes 10 items (e.g. "Most of the work life is wasted with meaningless activities"). It was developed by Hirschfeld and Field (2000). A 5-point Likert system was used to respond to the items. The higher score suggests greater alienation from the work. The reliability coefficient in this was 0.889 .

UCLA (University of California Los Angeles) Loneliness Scale was used to measure loneliness at work. This 5-point Likert scale was developed by Russell, Peplau and Ferguson (1978) and it consists of 20 items (e.g. "I feel isolated from others"). The reliability coefficient in this study was 0.880 .

\section{Results}

\subsection{Statistical Data Analysis}

SPSS 22.00 and AMOS 22.0 software programs were used to analyze and interpret the survey responses collected in the research. Regarding the scales used in the research, confirmatory 
factor analyses were conducted, followed by the calculation of the Cronbach's alpha values. Confirmatory factor analyses of three study scales were separately conducted via the AMOS program. A model was developed through structural equation modeling and the mediator analysis was performed on the AMOS program.

\subsection{Confirmatory Factor Analyses}

Structural equation modeling (SEM) and confirmatory factor analysis (CFA) are based on same logic and calculation technique in principle; however, they are approached as different concepts in practice. Structural equation modeling typically aims to test a proposed theoretical model or hypotheses and targets at establishing the model that explains the data best by comparing multiple alternative models. Therefore, structural equation modeling is considered an extension of traditional regression models (Schermelleh-Engel, Moosbrugger, \& Müller, 2003).

Confirmatory factor analysis, in turn, is usually used in scale development and validity analyses, and targets at confirming a predetermined or fictionalized structure. Confirmatory factor analysis is seen as a special application area of structural equation modeling and the measurement model is treated as a typical confirmatory analysis (Bollen, 1989; Blunch, 2008).

Table 3. Standard good fit indices and fit indices of the model

\begin{tabular}{|l|l|l|l|}
\hline No & \multicolumn{1}{|c|}{ Fit Indices } & \multicolumn{1}{c|}{ Good Fit } & \multicolumn{1}{c|}{ Acceptable Fit } \\
\hline 1 & $x^{2}$ & - & - \\
\hline 2 & $\mathrm{x}^{2} / \mathrm{s} \mathrm{d}$ & $0<\mathrm{x}^{2} / \mathrm{df}<2$ & $2<\mathrm{x}^{2} / \mathrm{sd}<5$ \\
\hline 3 & RMSEA & $0<\mathrm{RMSEA}<0.05$ & $0.05<\mathrm{RMSEA}<0.08$ \\
\hline 4 & GFI & $0.95<\mathrm{GFI}<1.00$ & $0.90<\mathrm{GFI}<0.95$ \\
\hline 5 & CFI & $0.97<\mathrm{CFI}<1.00$ & $0.95<\mathrm{CFI}<0.97$ \\
\hline 6 & SRMR & $0<\mathrm{SRMR}<0.05$ & $0.05<\mathrm{SRMR}<0.10$ \\
\hline
\end{tabular}

\subsection{Confirmatory Factor Analysis: Instruments}

With confirmatory factor analysis (CFA), AMOS 22.0 software program was used to investigate whether measurement models were significant for each scale. The results revealed that the measurement models were acceptable. Then, the adequacy of the entire model was evaluated through goodness of fit indices. In our research, only confirmatory factor analyses of the scales were conducted as the validity of language has been performed previously. Confirmatory factor analyses demonstrated that the dimensions of the scales were consistent with the original studies.

With increase in sample size, especially in samples greater than 200, the Chi-Square $\left(x^{2}\right)$ value is found higher and the statistical significance level of the Chi-Square (x2) test is found lower. 
Bollen, 1989; Fornell \& Larcker, 1981). The confirmatory factor analysis of the study scales and the adequacy of the general models tested were determined using degree of freedom-adjusted Chi-Square $\left(x^{2}\right)$ value (Chi-Square value/degree of freedom), other goodness of fit indices and standardized residual covariance matrix values (Bagozzi, Yi, \& Phillips, 1991).

\subsubsection{Turnover Scale}

In the confirmatory factor analysis of the turnover scale, which consists of three items and a single dimension, all items remained in the analysis with no exclusion. The analysis of three items revealed that the factor loadings of the items were between .811 and .98 .

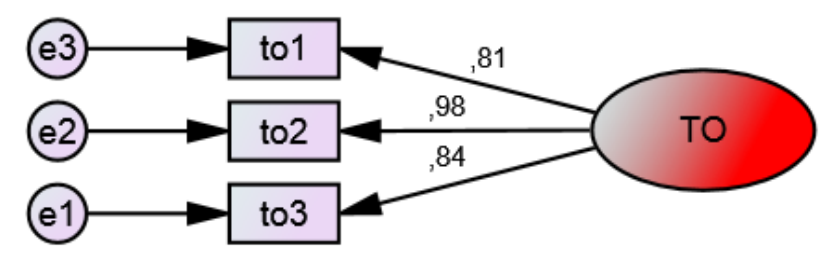

Figure 1. CFA Analysis of TO Scale

The model test values were found as $x^{2}(2.987)$ and $x^{2} / d f(2.987)$, suggesting that CFA was significant. Furthermore, the goodness of fit indices [GFI (.903), CFI (.0952), SRMR (.0547) and RMSEA (.0796)] were found within the acceptable limits, which showed CFA result to be applicable.

\subsubsection{Work Alienation Scale}

In the confirmatory factor analysis of the work alienation scale, which consists of 10 items and a single dimension, all items remained in the analysis with no exclusion. The analysis of 10 items revealed that the factor loadings of the items were between .68 and .86 . 


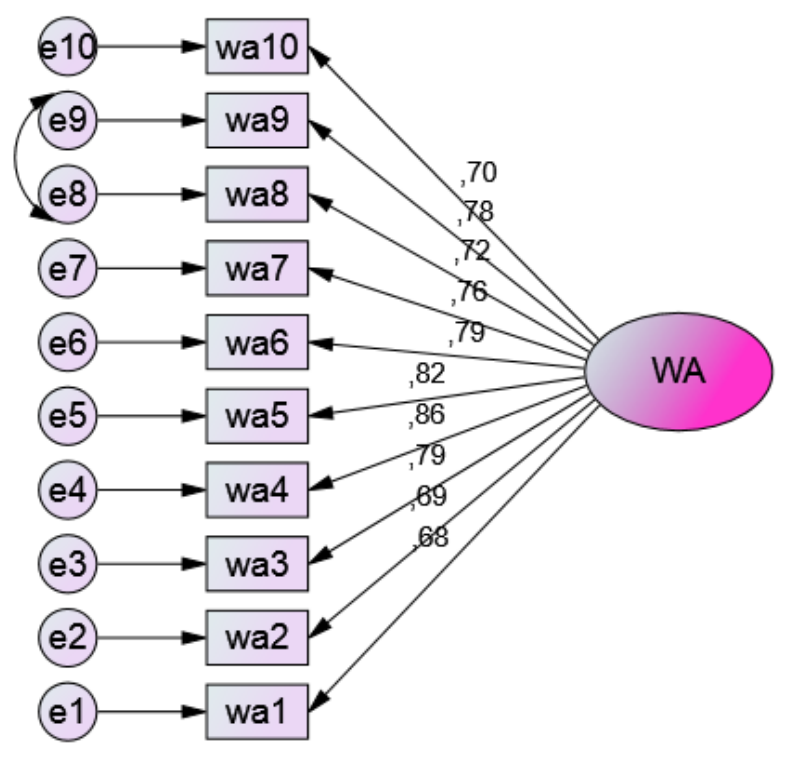

Figure 4. CFA analysis of WA Scale

The model test values were found as $x^{2}(76.140)$ and $x^{2} / d f(2.538)$, suggesting that CFA was significant. Furthermore, the goodness of fit indices [GFI (.967), CFI (.0984), SRMR (.0254) and RMSEA (.059)] was found within the acceptable limits, which showed CFA result to be applicable.

\subsubsection{UCLA Scale}

In the confirmatory factor analysis of the loneliness (UCLA) scale, which consists of 20 items and a single dimension, half of the items were excluded from the analysis due to low factor loadings. The analysis of 10 items that had significant factor loadings and remained in the analysis revealed that the factor loadings of the items ranged between .41 and .79 . 


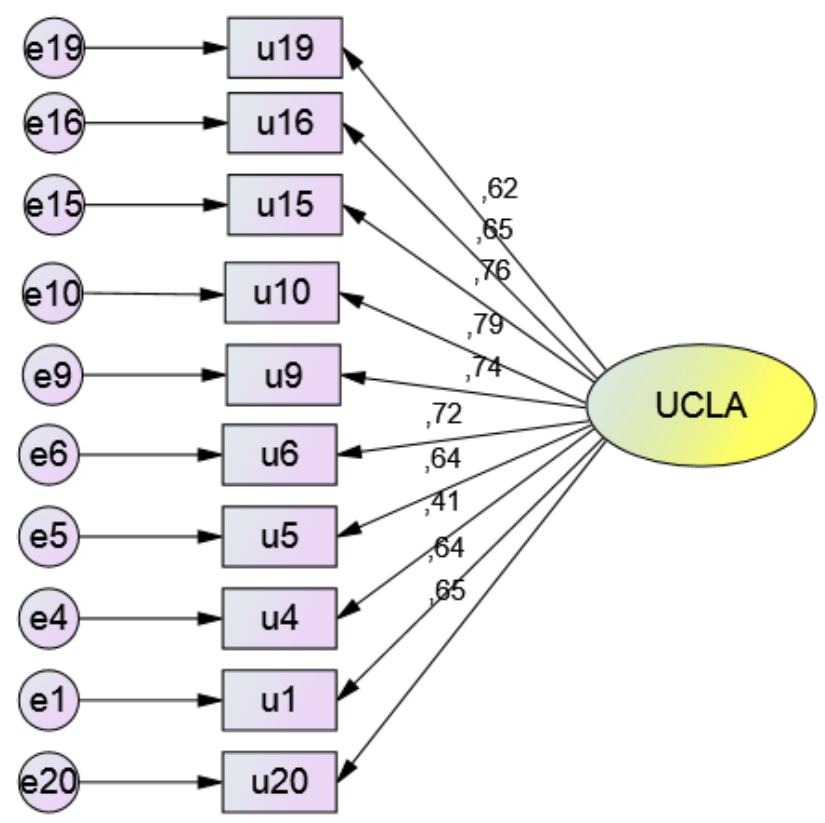

Figure 5. CFA analysis of UCLA Scale

The model test values were found as $x^{2}(76.140)$ and $x^{2} / d f(2.538)$, suggesting that CFA was significant. Furthermore, the goodness of fit indices [GFI (.967), CFI (.0984), SRMR (.0254) and RMSEA (.059)] was found within the acceptable limits, which showed CFA result to be applicable. 


\section{Macrothink}

6.4 Models

6.4.1 Model 1: The Effect of Work Alienation on Loneliness

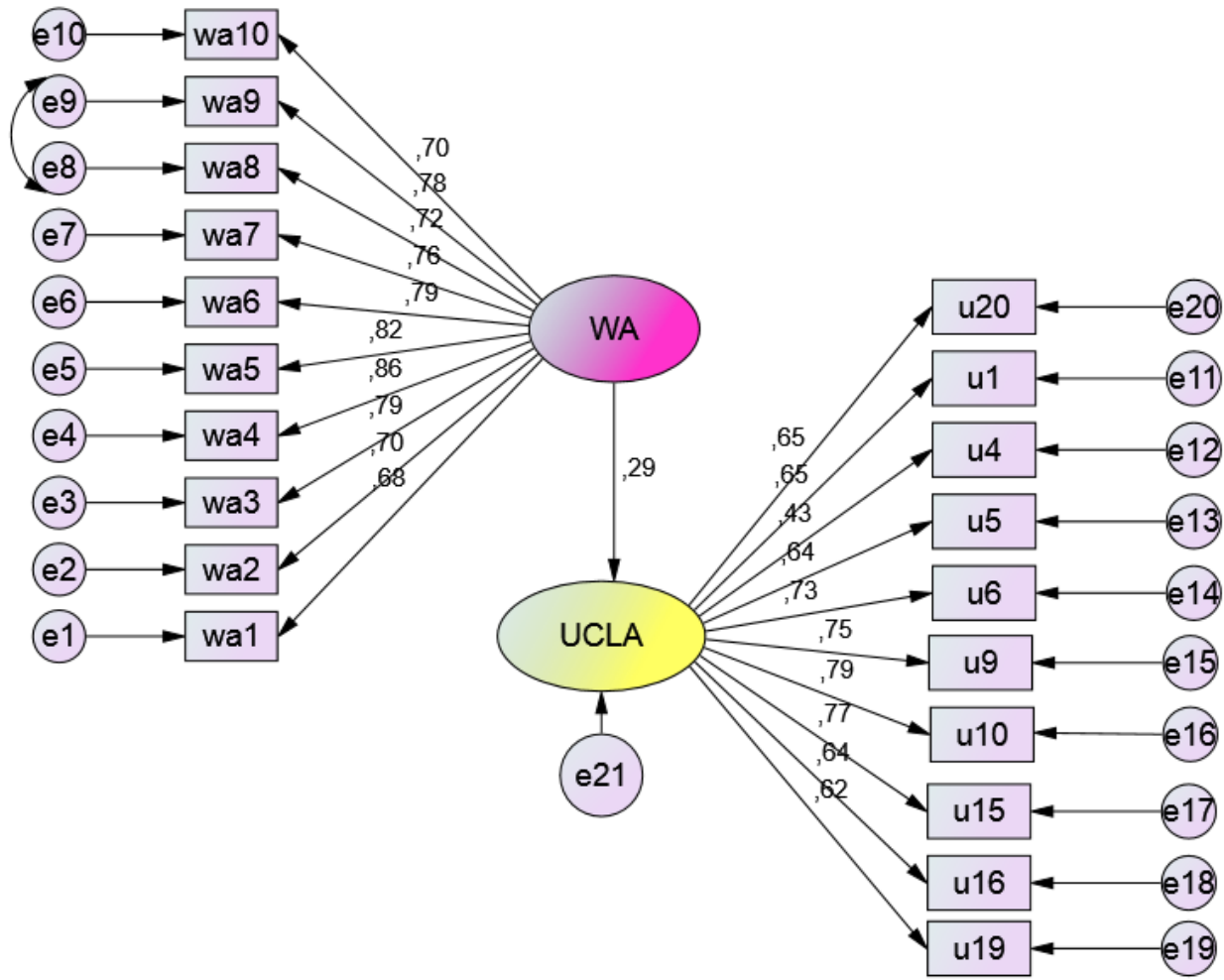

Figure 6. The effect of WA on UCLA

The model developed for examining the effect of WA on UCLA was found significant as the model test values were $x^{2}(260.385)$ and $x^{2} / d f(1.638)$. The model was within the acceptable limits as the goodness of fit indices was GFI (.944), CFI (.981), RMSEA (.038) and SRMR (.0321). The model developed for examining the effect of WA on UCLA was found valid according to both the Chi-Square test result and the good fit indices. The regression coefficient was $(.29, \mathrm{p}<0.05)$ regarding the effect of WA on UCLA from the estimate values, suggesting that the effect was statistically significant. Accordingly, the UCLA values increase as the WA values increase.

6.4.2 Model 2: The Effect of Turnover Intention on Loneliness 


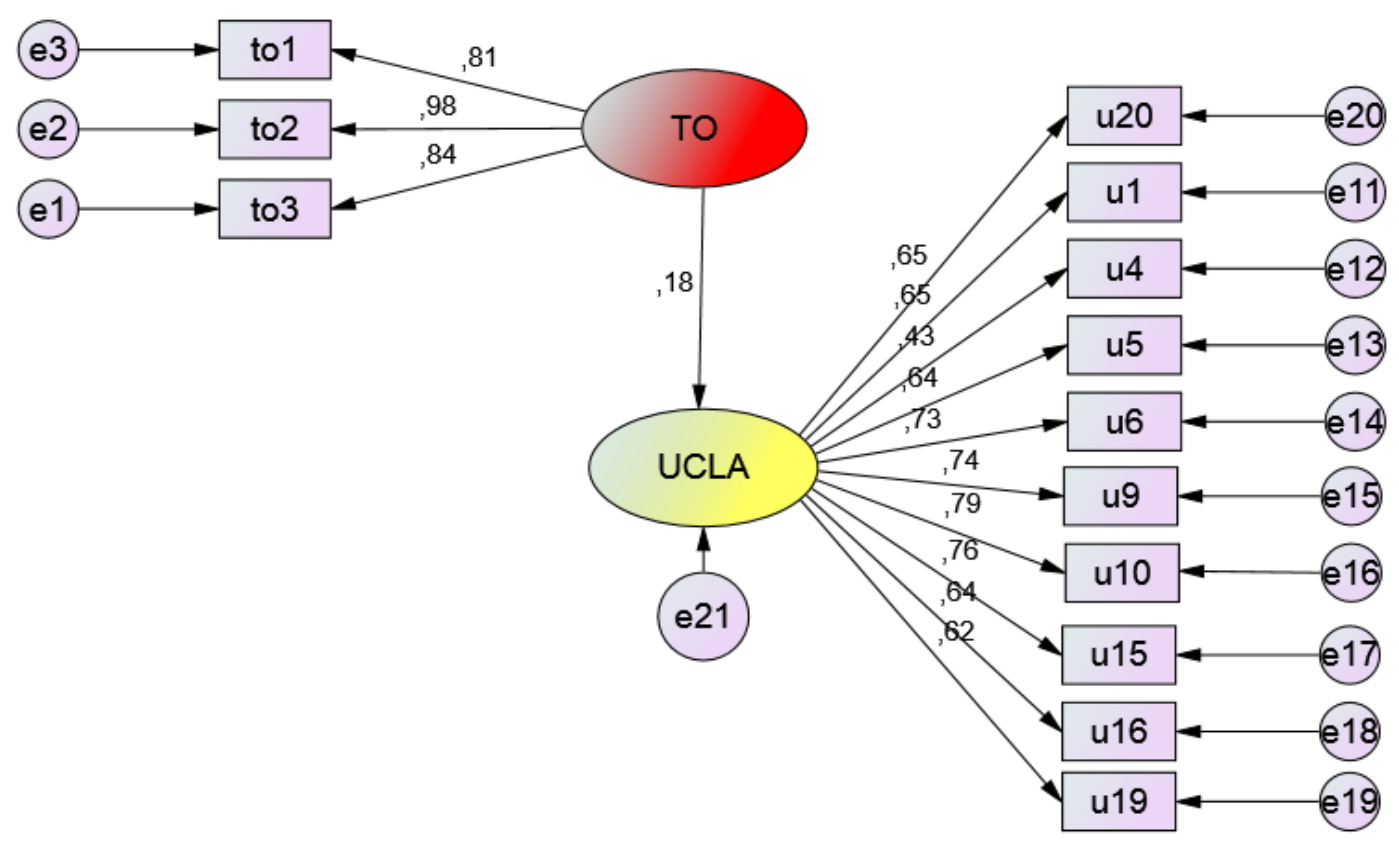

Figure 7. The Effect of TO on UCLA

The model developed for examining the effect of TO on UCLA was found significant as the model test values were $x^{2}(127.867)$ and $x^{2} / d f(2.131)$. The model was within the acceptable limits as the goodness of fit indices was GFI (.954), CFI (.981), RMSEA (.051) and SRMR (.043). The model developed for examining the effect of TO on UCLA was found valid according to both the Chi-Square test result and the good fit indices. The regression coefficient was $(.18, \mathrm{p}<0.05)$ regarding the effect of TO on UCLA from the estimate values, suggesting that the effect was statistically significant. Accordingly, the UCLA values increase as the turnover intention increases. 


\section{Macrothink}

6.4.3 The Mediating Role of Work Alienation in the Turnover Intention-Loneliness Relationship

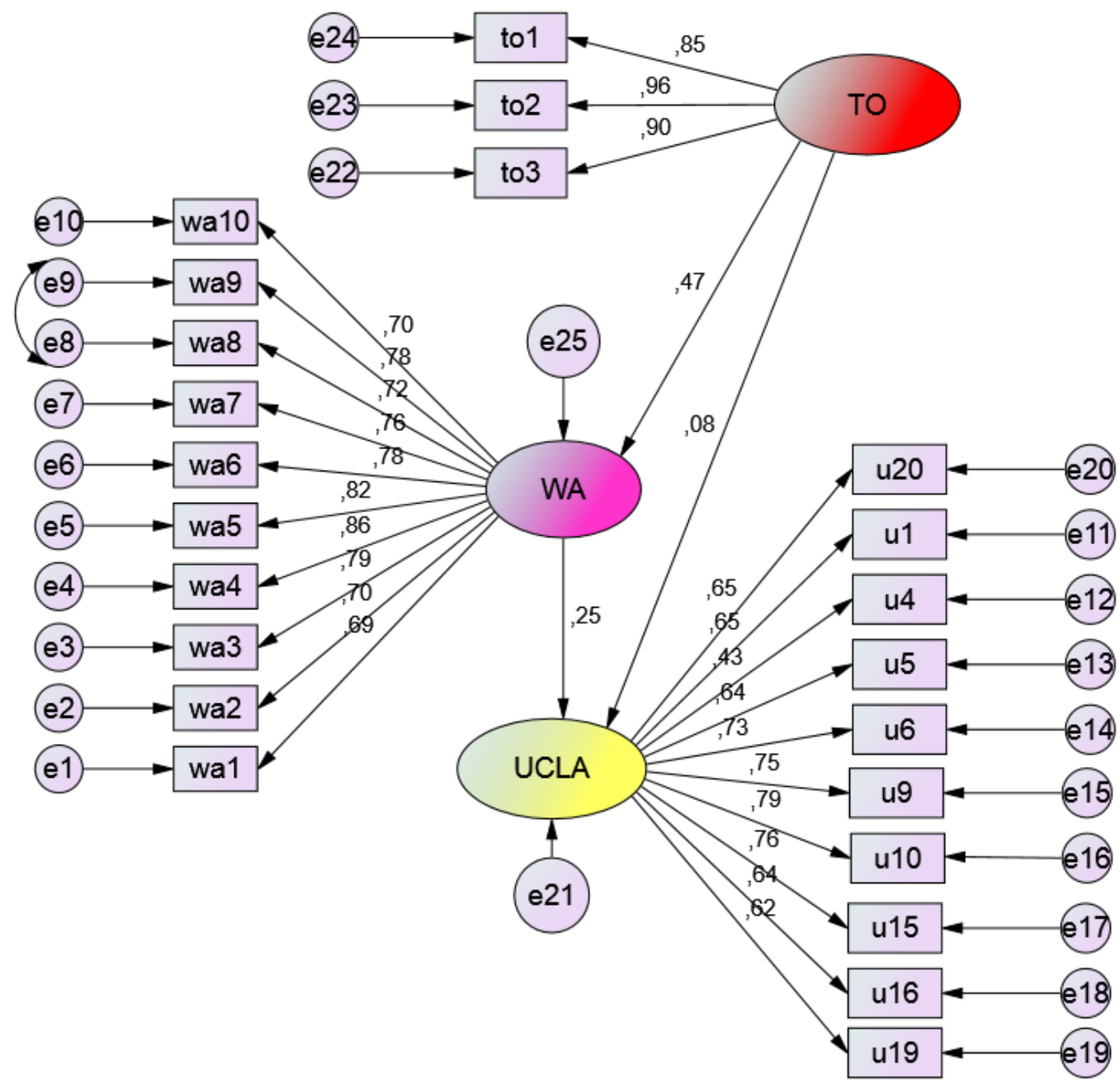

Figure 8. The Mediating Role of WA in the TO-UCLA Relationship

The model developed for examining the mediating role of WA in the impact of TO on UCLA was found significant as the model test values were $x^{2}$ (343.314) and $x^{2} / d f(1.582)$. The model was within the acceptable limits as the goodness of fit indices was GFI (.936), CFI (.981), RMSEA (.036) and SRMR (.0301). TO had an effect on UCLA in the singular relationship (.18), whereas the effect of TO on UCLA was found insignificant $(.08 ; \mathrm{p}>0.05)$ when WA was included in the TO-UCLA relationship. The decrease in effect from .18 to .08 revealed that WA fully mediated the TO-UCLA relationship. Turnover intention had an effect on loneliness and such effect of turnover intention on loneliness disappeared when work alienation came between. Accordingly, work alienation fully mediates the relationship between turnover intention and loneliness. 


\section{Conclusion and Suggestions}

In this study, we investigated the turnover intention and loneliness relationship as well as the mediating role of work alienation in this relationship. Our findings demonstrated that turnover intention had an effect on loneliness, a relationship that disappeared when work alienation came between. Consequently, work alienation was found to fully mediate the relationship between turnover intention and loneliness. This research contributes to the relevant literature by pointing out organizational behavior concepts that may lead to unexpected labor loss and thereby organizational inefficiency.

Our analyses indicate that organizations especially in the aviation industry should pay attention to psychological factors such as loneliness and work alienation that drive qualified employees to quit their jobs. As we assumed and found, loneliness at work has an effect on turnover intention. Since loneliness at work derives from poor interpersonal relations (Wright et al., 2006), this suggests that employees who have weaker social relations at the workplace have greater intention to quit their job, which is in agreement with the study by Demirbas and Haşit (2016). As loneliness indicates an undesired environment in an organization (Wright et al., 2006), such finding may help human resources management and executives to develop certain strategies to deal with the turnover issue. Accordingly, we recommend organizations to structure support meetings or interviews for employees who suffer from loneliness in order to create an area of self-expression. Additionally, organizations may provide trainings on communication skills and conflict management as well as social events to bring employees together. Organizations may also benefit from focusing more on teamwork and engagement-enhancing strategies.

The second finding of this study showed the mediating impact of work alienation on loneliness-turnover intention relationship. Organizations do not prefer the departure of their qualified employees against their own wishes. Top management of the organizations should not remain unresponsive to the resignation of a qualified employee because of certain psychological variables. The present study has highlighted that employees may quit their jobs not only due to financial causes but also due to certain psychological factors. As one of those factors, we established that alienation from work removes the impact of loneliness on turnover intention. Work alienation occurs when an employee feels unattached and uninterested in their job (Kanten \& Ülker, 2014) and such feeling is known to cause unfavorable outcomes both at the organizational and individual levels (Ceylan \& Sulu, 2011; Chiaburu et al., 2013). Therefore, employers must strive to prevent employees from feeling detached from their organizations. Based on the study by Develioğlu and Tekin (2012), employees who have been working in an organization less than a year feel greater alienation from work than those who have been working in the same organization more than 10 years. Accordingly, organizations may consider increasing work autonomy and participation in decision-making processes to enhance employees' respect and engagement toward their job. Furthermore, organizations may hold regular interviews to find out situational issues experienced by employees and develop necessary strategies. 
Although our study has its benefits, it holds certain limitations. First, this study was conducted only with aviation employees. Future research may include other service industries to make a comparison or discover industry-specific differences leading to turnover intention. Second, future research may investigate cultural factors contributing to these psychological factors influencing turnover intention, such as organizational climate and the type of organizational culture. Moreover, other situational and individual factors may be explored in future research.

\section{References}

Arshadi, N., \& Shahbazi, F. (2013). Workplace characteristics and turnover intention: Mediating role of emotional exhaustion. Procedia-Social and Behavioral Sciences, 84, 640-645. http://dx.doi.org/10.1016/j.sbspro.2013.06.618

Aykan, E. (2014). Effects of perceived psychological contract breach on turnover intention: Intermediary role of loneliness perception of employees. Procedia - Social and Behavioral Sciences, 150, 413-419. http://dx.doi.org/10.1016/j.sbspro.2014.09.040

Aytaç, S. (2015). Loneliness as mediator between job satisfaction and intention to leave: A study on prison staff in Turkey. Arabian Journal of Business Management Review, 5(6), 167.

Bagozzi, R.P., Yi, Y., \& Phillips, L.W. (1991). Assessing construct validity in organizational research. Adminstrative Science Quarterly, 36(3), 421-58. http://dx.doi.org/ 10.2307/2393203

Bakker, A.B., Schaufeli, W.B., Leiter, M.P., \& Taris, T.W. (2008). Work engagement: An emerging concept in occupational health psychology. Work \& Stress, 22, 187-200. http://dx.doi.org/10.1080/02678370802393649

Banai, M., \& Reisel, W. D. (2007). The influence of supportive leadership and job characteristics on work alienation: A six-country investigation. Journal of World Business, 42(4), 463-476. http://dx.doi.org/10.1016/j.jwb.2007.06.007

Bester, F. (2012). A model of work identity in multicultural work settings (Doctoral dissertation). University of Johannesburg, Johannesburg.

Blunch, N. J. (2008). Introduction to structural equation modeling using SPSS and AMOS. Thousand Oaks, CA: Sage. http://dx.doi.org/ 10.4135/9781446249345

Blauner, R. (1964). Alienation and freedom: The factory worker and his industry. Chicago: University of Chicago Press.

Bollen, K. A. (1989). Structural equations with latent variables. New York: Wiley. http://dx.doi.org/10.1002/9781118619179

Cammann, C., Fichman, M., Jenkins, G.D., \& Klesh, J.R. (1983). Assessing the attitudes and perceptions of organizational members. In S.E. Seashore, E.E. Lawler, P.H. Mirvis and C. Cammann (Eds.), Assessing organizational change: A guide to methods, measures, and practices. New York: John Wiley and Sons, 71-138. 


\section{Macrothink}

Cascio, W. F. (2010). Managing human resources: Productivity, quality of work life, profits. Boston: McGraw-Hill/Irwin.

Ceylan, A., \& Sulu, S. (2011). Organizational injustice and work alienation. E\&M Economics and Management, 2, 65-78.

Chacon, F., Vecina, M. L., \& Davila, M. C. (2007). The three-stage model of volunteers' duration of service. Social Behavior and Personality, 35(5), 627-642.

Chiaburu, D. S., Diaz, I., \& De Vos, A. (2013). Employee alienation: relationships with careerism and career satisfaction. Journal of Managerial Psychology, 28(1), 4-20. http://dx.doi.org/10.1108/02683941311298832

Dalessio, A., Silverman, W. H., \& Schuck, J. R. (1986). Paths to turnover: A re- analysis and review of existing data on the Mobley, Horner and Hollingworth turnover model. Human Relations. 39(3), 264-70. http://dx.doi.org/10.1177/001872678603900305

Demir, A. (1989). UCLA yalnızlık ölçeğinin geçerlik ve güvenilirliği. Psikoloji Dergisi, 7(23), 14-18.

Demirbaş, B., \& Haşit, G. (2016). İş yerinde yalnızlık ve işten ayrılma niyetine etkisi: Akademisyenler üzerine bir uygulama. Anadolu Üniversitesi Sosyal Bilimler Dergisi, 16(1), 137-158.

Develioğlu, K., \& Tekin, Ö. A. (2012). Investigation of hotel employees' level of alienation within the context of demographic characteristics. International Journal of Alanya Faculty of Business, 4(3), 121-128.

Doğan, T., Çetin, B., \& Sungur, M. Z. (2009). İş yaşamında yalnızlık ölçeği Türkçe formunun geçerlilik ve güvenilirlik çalışması. Anadolu Psikiyatri Dergisi, 10, 271-277.

DiPietro, R. B., \& Pizam, A. (2008). Employee alienation in the quick service restaurant industry. Journal of Hospitality and Tourism Research, 32, 22-39. http://dx.doi.org/10.1177/1096348007309567

Erdil, O., \& Ertosun, Ö.G. (2011). The relationship between social climate and loneliness in the workplace and effects on employee well-being. Procedia Social and Behavirol Sciences, 24, 505-525. http://dx.doi.org/10.1016/j.sbspro.2011.09.091

Fishbein, M., \& Ajzen, I. (1975). Belief, attitude, intention and behavior: An introduction to theory and research. Reading, MA: Addison-Wesley.

Fornell, C., \& Larcker, D. F. (1981). Evaluating structural equation models with unobservable variables and measurement error. Journal of Marketing Research 18(1), 39-50. http://dx.doi.org/10.2307/3151312

Fromm, E. (1955). The sane society. New York: Rinehart. 
Golden, T. D., Veiga, J. F., \& Dino, R. N. (2008). The impact of professional isolation on teleworker job performance and turnover intentions: Does time spent teleworking, interacting fact-to-face, or having access to communication enhancing technology matter? Journal of Applied Psychology, 93, 1412-1421. http://dx.doi.org/10.1037/a0012722

Hewitt Associates. (2004, February). Strategies for cost management of the HR function. Timely Topics. Retrieved from http://hrledger.com/library/HR_Costs_Hewitt_2004.pdf

Hirschfeld, R. R., \& Field, H. S. (2000). Work centrality and work alienation: Distinct aspects of a general commitment to work. Journal of Organizational Behavior, 21(7), 789-800.

http://dx.doi.org/10.1002/1099-1379(200011)21:7\%3C789::AID-JOB59\%3E3.0.CO;2-W

Hom, P.W., \& Griffeth, R. W. (1991). A structural equations modeling test of a turnover theory: Crosssectional and longitudinal analysis. Journal of Applied Psychology, 76, 350-366.

Hwang, I. S., \& Kou, J. H. (2006). Effects of job satisfaction and perceived alternative employment opportunities on turnover intention: An examination of public sector organizations. Journal of American Academy of Business, Cambridge, 8(2), 254-255.

Igbaria, M., \& Greenhaus, J. (1992). Determinants of MIS employees' turnover intentions: A structural equation model. Communications of the ACM, 35(2). http://dx.doi.org/10.1145/129630.129631

Kanten, P., \& Ülker, F. (2014). Yönetim tarzinin üretkenlik karşiti iş davranişlarina etkisinde işe yabancılaşmanın aracılık rolü. Muğla Sitkı Koçman Üniversitesi Sosyal Bilimler Ensitüsü Dergisi, 32, 16-40.

Kanungo, R. N. (1979). The concepts of alienation and involvement revisited. Psychological Bulletin, 86, 119-138. http://dx.doi.org/10.1037/0033-2909.86.1.119

Kaymaz, K., Eroğlu, U., \& Sayılar Y. (2014). Effect of loneliness at work on the employees' intention to leave. "İş, Güç" Industrial Relations and Human Resources Journal, 16(1), 38-53.

Kraus, L.A., Davis, M.H., Bazzini, D., Church, M., \& Kirchman, C.M. (1993). Personal and social influences on loneliness: The mediating effect of social provisions. Social Psychology Quarterly, 56(1), 37-53. http://dx.doi.org/10.2307/2786644

Lacity, M. C., Lyer, V. V., \& Rudramuniyaiah, P. S. (2008). Turnover intentions of Indian IS professionals. Information Systems Frontiers on Outsourcing, 10, 225-241. http://dx.doi.org/10.1007/978-3-540-88851-2_18

Liu, B., Liu, J. \& Hu, J. (2010). Person organization fit, job satisfaction, and turnover intention: An empirical study in the Chinese public sector. Social Behavior and Personality, 38(5), 615-626. http://dx.doi.org/10.2224/sbp.2010.38.5.615 
Lodahl, T. M., \& Kejner, M. (1965). The definition and measurement of job inventory. Journal of Applied Psychology, 43, 24-33. http://dx.doi.org/10.1037/h0021692

Maadi, S. R., Kobasa, S. C., \& Hoover, M. (1979). An alienation test. Journal of Humanistic Psychology, 19, 73-76. http://dx.doi.org/10.1177/002216787901900407

Mathieu, J., \& Zajac, D. (1990). A review and meta-analysis of the antecedents, correlates, and consequences of organisational commitment. Psychological Bulletin, 108, 171-194. http://dx.doi.org/10.1037/0033-2909.108.2.171

Mobley, W. H. (1982). Employee turnover: Causes, consequences, and control. Addison-Wesley, Reading, MA.

Mobley, W., Horner, O., \& Hollingsworth, A. (1978). An evaluation of precursors of hospital employee turnover. Journal of Applied Psychology, 63(4), 408-414. http://dx.doi.org/10.1037/0021-9010.63.4.408

Nair, N., \& Vohra, N. (2010). An exploration of factors predicting work alienation of knowledge workers. Management Decision, 48(4), 600-615. http://dx.doi.org/10.1108/00251741011041373

Nurmi, J., \& Katariina, S. (1997). Social strategies and loneliness: A prospective study. $\begin{array}{lll}\text { Personality and Individual 205-215. } & \text { Differences, }\end{array}$ http://dx.doi.org/10.1016/S0191-8869(97)00039-1

Organ, D. W., \& Greene, C. N. (1981). The effects of formalization on professional involvement: A compensatory process approach. Administrative Science Quarterly, 26, 237-252. http://dx.doi.org/10.2307/2392471

Podsakoff, P. M., Williams, L. J., \& Todor, W. D. (1986). Effects of organizational formalization on alienation among professionals and nonprofessionals. Academy of Management Journal, 29(4), 820-831. http://dx.doi.org/10.2307/255948

Robbins, S. P., Judge, T.A., Odendaal, A., \& Roodt, G. (2009). Organisational behavior: Global and Southern African perspectives (2nd ed.). Johannesburg: Prentice Hall.

Rook, K. S. (1984). Promoting social bonding: Strategies for helping the lonely and socially $\begin{array}{llll}\text { isolated. American } & \text { Psychologist, } & \text { 39(12), }\end{array}$ http://dx.doi.org/10.1037/0003-066X.39.12.1389

Rusbult, C. E., Farrell, D., Rogers, G., \& Mainous III, A. G. (1988). Impact 714 of exchange variables on 715 exit, voice, loyalty, and neglect: An integrative model of responses to declining job satisfaction. Academy of Management Journal, 31(3), 599-627.

Russell, D., Peplau, L. A., \& Ferguson, M. L. (1978). Developing a measure of loneliness. $\begin{array}{llll}\text { Journal of Personality 290-294. } & \text { Assessment, }\end{array}$ http://dx.doi.org/10.1207/s15327752jpa4203_11 
Savikko, N., Routasalo, P., Tilvis, R. S., Strandberg, T. E. \& Pitlaka, K.H. (2005). Predictors and subjective causes of loneliness in an aged population. Archives of Gerontology and Geriatrics, 41, 223-233. http://dx.doi.org/10.1016/j.archger.2005.03.002

Schermelleh-Engel, K., Moosbrugger, H., \& Müller, H. (2003). Evaluating the fit of structural equation models. Methods of Psychological Research, 8(2), 23-74.

Seeman, M. (1959). On the meaning of alienation. American Sociological Review, 24, 783-791. http://dx.doi.org/10.2307/2088565

Seeman, M. (1983). Alienation motifs in contemporary theorizing: The hidden continuity of the classic themes. Social Psychology Quarterly, 171-184. http://dx.doi.org/10.2307/3033789

Sias, P. M., \& Cahill, D. J. (1998). From coworkers to friends: The development of peer friendships in workplace. Western Journal of Communication, 62(3), 273-299. http://dx.doi.org/10.1080/10570319809374611

Sousa-Poza, A., \& Henneberger, F. (2004). Analyzing job mobility with job turnover intentions: An international comparative study. Journal of Economic Issues, 82(1), 1-28. http://dx.doi.org/10.1080/00213624.2004.11506667

Suárez-Mendoza, M. J., \& Zoghbi-Manrique-De-Lara, P. (2008). The impact of work alienation on organizational citizenship behavior in the Canary Islands. International Journal of Organizational Analysis, 15(1), 56-76.

Sulu, S., Ceylan, A., \& Kaynak, R. (2010). Work alienation as a mediator of the relationship between organizational injustice and organizational commitment: Implications for healthcare professionals. International Journal of Business and Management, 5(8), 27-38. http://dx.doi.org/10.5539/ijbm.v5n8p27

Şahin, F. (2011). Lider-üye etkileşimi ile işten ayrılma niyeti arasındaki ilişki üzerinde cinsiyetin etkisi. Ege Akademik Bakıs, 2, 277-288.

Taboli, H. (2015). Burnout, Work Engagement, work alienation as predictors of turnover intentions among universities employees in Kerman. Life Science Journal, 12(9), 67-74.

Telli, E., Ünsar, A. S, \& Oğuzhan, A. (2012). Liderlik davranış tarzlarının çalışanların örgütsel tükenmişlik ve işten ayrılma eğilimleri üzerine etkisi: Konuyla ilgili bir uygulama. Electronic Journal of Vocational Colleges, 2, 135-150.

Tett, R. P., \& Meyer, J. P. (1993). Job satisfaction, organizational commitment, turnover intention, and turnover: Path analyses based on meta-analytic findings. Personnel Psychology, 46(2), 259-293. http://dx.doi.org/10.1111/j.1744-6570.1993.tb00874.x

Tuna, M., \& Yeşiltaş, M. (2014). The effect of ethical climate, work alienation and organizational identification on turnover intention: A research on hotel establishments. Anatolia: Turizm Araştırmaları Dergisi, 25(1), 105-117. 
Ünsar, A. S., \& Karahan, D. (2011). Yabancılaşmanın işten ayrılma eğilimine etkisini belirlemeye yönelik bir alan araştırması, Sosyal ve Ekonomik Araştırmalar Dergisi, 15(21), 361-379.

van Dick, R., Christ, O., Stellmacher, J., Wagner, U., Ahlswede, O., Grubba, C... Tissington, P. A. (2004). Should I stay or should I go? Explaining turnover intentions with organizational identification and job satisfaction. British Journal of Management, 15(4), 351-360. http://dx.doi.org/10.1111/j.1467-8551.2004.00424.x

van Knippenberg, D., van Dick, R., \& Tavares, S. (2007). Social identity and social exchange: Identification, support, and withdrawal from the job. Journal of Applied Social Psychology, 37(3), 457-477. http://dx.doi.org/10.1111/j.1559-1816.2007.00168.x

Vandenberg R. J., \& Nelson J. B. (1999). Disaggregating the motives underlying turnover intentions: When do intentions predict turnover behaviour? Human Relations, 52(10), 1313-1336. http://dx.doi.org/ 10.1023/A:1016964515185

Weiss, R. S. (1973). Loneliness: The experience of emotional and social isolation. Cambridge, MA: MIT Press, Cambridge.

Wright, S. L., Burt, C. D. B., \& Strongman, K. T. (2006). Loneliness in the workplace: Construct definition and scale development. New Zeland Journal of Psychology, 35(2), 59-68.

Yıldırım, M. H., Erul, E. E., \& Kelebek, P. (2014). Tükenmişlik ile işten ayrılma niyeti arasındaki ilişki: Banka çalışanları üzerine bir araştırma. Organizasyon ve Yönetim Bilimleri Dergisi, 6(1), 34-44.

Y1lmaz, E. (2008). Organizational commitment and loneliness and life satisfaction levels of school principles. Social Behavior and Personality, 36(8), 1085-1096.

\section{Copyright Disclaimer}

Copyright for this article is retained by the author(s), with first publication rights granted to the journal.

This is an open-access article distributed under the terms and conditions of the Creative Commons Attribution license (http://creativecommons.org/licenses/by/3.0/). 